\title{
Capecitabine and Oral Cyclophosphamide Combination in Taxane/Antrhracycline Resistant Metastatic Breast Cancer
}

\author{
Ahmet OZET, Dogan UNCU, Okan KUZHAN, Seref KOMURCU, Mustafa OZTURK, \\ Fikret ARPACI, Bekir OZTURK \\ Gulhane Military Medical Academy, Faculty of Medicine, Department of Medical Oncology, Ankara, TURKEY
}

\begin{abstract}
No combination chemotherapy has been shown yet to be more effective in metastatic breast cancer (MBC) patients who did not either respond to taxanes and anthracyclines or recurred thereafter. We aimed to report in short term the effect and toxicity results of capecitabine and oral cyclophosphamide combination in MBC patients with anthracyclin and taxane resistance.

Between January and September 2007, totally 11 patients were enrolled. All of them had received anthracyclines and taxanes previously either in metastatic or adjuvant setting. They were given capecitabine $\left(1000 \mathrm{mg} / \mathrm{m}^{2}\right.$ bid) and oral cychlophosphamide $\left(30 \mathrm{mg} / \mathrm{m}^{2}\right.$ tid) on days 1 to 14 every 3 weeks.

Median age of patients was 48 years. The median number of previous chemotherapy lines given was 3 . Seven patients had received trastuzumab previously, either as monotherapy or as part of combination chemotherapy. Seven had received capecitabine monotherapy before. Median follow-up was 5 months. The patients received a median of 8 cycles chemotherapy. In 4 patients (36.4\%) partial response was obtained. Five patients (45.5\%) remained stable, and 2 (18.1\%) progressed. Median duration of response was 5 months. At the analysis time, 2 patients were dead. Totally 2 patients (18.1\%) had grade 2 leucopenia, $2(18.1 \%)$ had grade 2 hand-foot syndrome, 1 (9.1\%) had grade 3 hand-foot syndrome.

Capecitabine and oral cyclophosphamide combination is a promising and well tolerated regimen in patients who previously had received taxanes and anthracyclines and in patients with cerbB2 positive tumors who received trastuzumab previously.
\end{abstract}

Keywords: Breast neoplasms, Cyclophosphamide, Capecitabine

\section{ÖZET}

Antrasiklin ve Taksan Rezistan Metastatik Meme Kanserli Hastalarda Kapesitabin ve Oral Siklofosfamid Kombinasyonu

Taksan ve antrasiklinlere yanıt vermeyen veya bu tedaviler sonrasında tekrarlayan metastatik meme kanserli hastalarda daha etkili olduğu gösterilen bir kombinasyon kemoterapisi bulunmamaktadır. Taksan ve antrasiklin rezistan metastatik meme kanserli hastalarda kapesitabin ve oral siklofosfamid kombinasyonunun kısa dönemde etkinliği ve toksisitesini bildirmeyi amaçladık.

Ocak ve Eylül 2007 tarihleri arasında toplam 11 hasta çalışmaya alındı. Hastaların hepsi ya adjuvant ya da metastatik dönemde taksan ve antrasiklin tedavisi almışlardı. Hastalara 3 haftada bir 1-14 günler arasında kapesitabin $\left(1000 \mathrm{mg} / \mathrm{m}^{2}\right.$ günde 2 defa) ve oral siklofosfamid (30 mg/m² günde 3 defa) verildi. 
Hastaların ortanca yaşı 48 idi. Önceden aldıkları ortanca kemoterapi rejimi sayısı 3 idi. Yedi hasta ya tek başına ya da kombinasyon kemoterapisi parçası olarak trastuzumab tedavisi almıştı. Yedi hasta önceden kapesitabin monoterapisi almıştı. Ortanca takip süresi 5 ay idi. Hastalar ortanca 8 kür kemoterapi aldı. Dört (\%36.4) hastada parsiyel yanıt alındı. Beş (\%45.5) hasta stabil kaldı, 2 (\%18.1) hastada progresyon gözlendi. Ortanca yanıt süresi 5 ay idi. Değerlendirme anında 2 hasta ölmüştü. Toplam olarak 2 (\%18.1) hastada grad 2 lökopeni, 2 (\%18.1) hastada grad 2 el-ayak sendromu ve 1 (\%9.1) hastada grad 3 el-ayak sendromu gelişti.

Kapesitabin ve oral siklofosfamid kombinasyonu önceden taksan, antrasiklin ve cerbB2 pozitif tümörler için trastuzumab tedavisi almış hastalarda iyi tolere edilen ve ümit verici bir rejimdir.

Anahtar Kelimeler: Meme kanseri, Siklofosfamid, Kapesitabin

\section{INTRODUCTION}

Metastatic breast cancer (MBC) is an incurable disease. Palliation of symptoms, maintenance of quality of life and tolerability of treatment are particularly important for patients. The most commonly used chemotherapeutic regimens in the treatment of MBC include anthracyclines and taxanes, either in sequence or in combination. ${ }^{1}$ An increasing number of patients receive an anthracycline-taxane combination as adjuvant therapy, requiring the development of new combinations for the treatment of metastatic disease. No monotherapy or combination chemotherapy has been shown yet to be more effective in metastatic breast cancer patients who did not either respond to taxanes and anthracyclines or recurred thereafter.

Both cyclophosphamide and capecitabine have some efficacy in breast cancer. Cyclophosphamide is typically used as a component of combination regimens, such as CAF (cyclophosphamide, adriamycin, 5-fluorouracil) or TAC (docetaxel, adriamycin, cyclophosphamide). The oral fluoropyrimidine capecitabine, generates 5 -fluorouracil preferentially at the tumor site through exploitation of the significantly higher concentration of thymidine phosphorylase in tumor versus normal tissue. ${ }^{2}$ Capecitabine monotherapy has demonstrated consistently high activity and excellent tolerability in anthracycline- and/or taxane-pretreated MBC., ${ }^{3,4}$ The high single-agent activity and good tolerability of capecitabine makes it an attractive combination partner.

Several surveys have shown that most patients prefer oral treatment instead of intravenous therapy. ${ }^{5-7}$ Nevertheless, a minority of patients prefer intravenous therapy because they believe that oral therapy is less effective than intravenous treatment. ${ }^{7-9} \mathrm{We}$ aimed to report the efficacy and toxicity of capecitabine and oral cyclophosphamide combination in anthracyclin and taxane resistant MBC patients.

\section{PATIENTS AND METHODS}

Between January and September 2007, totally 11 histologically confirmed MBC patients were enrolled into the study. All of them had received anthracyclines and taxanes previously either in metastatic or adjuvant setting. They received capecitabine $\left(1000 \mathrm{mg} / \mathrm{m}^{2}\right.$ bid) and oral cychlophosphamide (30 $\mathrm{mg} / \mathrm{m}^{2}$ tid) on days 1 to 14 every 3 weeks. The chemotherapy continued until progression or intolerance. Depending on the RECIST criteria ${ }^{10}$, response to treatment was evaluated with imaging studies every three cycles. Duration of response was calculated by counting the months elapsed from the established response to progression or to analysis time. Toxicity was graded according to the NCI Common Terminology Criteria for Adverse Events version 3.0.

\section{RESULTS}

Patient's and tumor characteristics were summarized in Table 1. The median age was 48 years (range, 33-60). All patients had a good performance status (ECOG PS 0-2). All of them had received anthracyclines and taxanes previously either in metastatic or adjuvant setting. Seven patients had received trastuzumab previously, either as monotherapy or as part of combination chemotherapy. The median number of previous chemotherapy lines given was 3 (range: 2-7). The major metastatic sites were lung, bone and liver in order. 


\begin{tabular}{|ll|}
\hline Table 1. Patient's characteristics & \\
\hline Parameter & $\mathbf{n}$ \\
\hline No. of patients & 11 \\
Age, years median (range) & 48 (33-60) \\
ECOG performance status & \\
0 & 3 \\
1 & 7 \\
2 & 1 \\
Menopausal status & \\
Premenopausal & 5 \\
Postmenopausal & 6 \\
Hormonal receptor status & \\
Estrogen receptor (+/-) & \\
Progesterone receptor (+/-) & $5 / 6$ \\
cerbB-2 (+/-/unknown) & $4 / 7$ \\
Disease at presentation & $7 / 3 / 1$ \\
Stages I/IIIII/IV & \\
Predominant metastatic sites & $0 / 6 / 4 / 1$ \\
Liver & \\
Lung & 2 \\
Bone & 5 \\
Previous chemotherapy & \\
Anthracycline & \\
Taxane & 71 \\
Trastuzumab & \\
Capecitabine & \\
\hline
\end{tabular}

\begin{tabular}{|ll|}
\hline \multicolumn{2}{|l|}{ Table 2. Response evaluation } \\
\hline Response & $\mathbf{n}(\%)$ \\
\hline Complete & 0 \\
Partial & $4(36.4 \%)$ \\
Stable & $5(45.5 \%)$ \\
Progression & $2(18.1 \%)$ \\
\hline
\end{tabular}

Median follow-up was 5 months (range: 2-11). The patients received a median of 8 cycles chemotherapy (range: 2-15). All of 11 patients were evaluated for response: $4(36.4 \%)$ patients achieved a partial response and none had complete response (Table 2). All patients with partial response had received capecitabine monotherapy previously. Median duration of response was 5 (range: 3-8) months. Two $(18.1 \%)$ patients died related to the disease progression.

Toxicity evaluations are summarized in Table 3 . One $(9.1 \%)$ patient had grade 3 hand-foot syndrome. No grade 4-5 toxicity observed.

\begin{tabular}{|c|c|c|c|c|}
\hline \multirow[t]{2}{*}{ Laboratory parameter } & \multicolumn{4}{|c|}{ Number of patients } \\
\hline & Grade 1 & Grade 2 & Grade 3 & Grade 4 \\
\hline \multicolumn{5}{|l|}{ Hematological } \\
\hline Leukopenia & 1 & 2 & 0 & 0 \\
\hline Anemia & 1 & 0 & 0 & 0 \\
\hline Thrombocytopenia & 0 & 0 & 0 & 0 \\
\hline \multicolumn{5}{|l|}{ Non-hematological } \\
\hline Nausea/vomiting & 2 & 0 & 0 & 0 \\
\hline Diarrhea & 1 & 0 & 0 & 0 \\
\hline Hand-foot syndrome & 1 & 2 & 1 & 0 \\
\hline Sensory/motor neuropathy & 1 & 0 & 0 & 0 \\
\hline Fatigue & 2 & 0 & 0 & 0 \\
\hline AST and/or ALT elevation & 2 & 0 & 0 & 0 \\
\hline
\end{tabular}




\section{DISCUSSION}

There is no evidence that any specific chemotherapy combination is superior to any other in metastatic breast cancer patients who did not either respond to taxanes and anthracyclines or recurred thereafter. New treatment strategies are increasingly needed for patients failing these therapies or who are at risk of cumulative toxicities. There is no study in the literature investigating the efficacy of the capecitabine and cyclophosphamide combination after taxanes and antracyclines in MBC patients. Capecitabine has been demonstrated to be effective in this setting with an overall response rate of 9$28 \%$, and overal survival between 9.4 and 15.2 months in several phase II-III trials, either as monotherapy or combination chemotherapy. ${ }^{11-14}$

In a phase I study investigating the feasibility of the combination of capecitabine $\left(1000-1331 \mathrm{mg} / \mathrm{m}^{2}\right.$ on days 1 to 28 every 4 weeks) and oral cyclophosphamide $\left(50-125 \mathrm{mg} / \mathrm{m}^{2}\right.$ on days 1 -to 14 , every 4 weeks), this combination was found to be feasible and tolerable..$^{15}$ Shinji et al reported the combination of capecitabine $829 \mathrm{mg} / \mathrm{m}^{2}$ bid and oral cyclophosphamide $33 \mathrm{mg} / \mathrm{m}^{2}$ bid on days 1 to 14 every 3 weeks to be an active and tolerable regimen. ${ }^{16}$ In that study, 16 patients received this combination in the first line, and the overall response rate was $40 \%$. However in our study overall response rate was $36.4 \%$ and this rate was achieved in patients with previous taxan or antracycline exposure (the median number of previous chemotherapy lines was 3 ). All of our patients with cerbB 2 positive tumors had received trastuzumab. Interestingly patients who progressed on previous capecitabine monotherapy or recurred thereafter responded to the capecitabine and cyclophosphamide combination, cyclophosphamide might have broken the capecitabine resistance. We didnot give the median progression free and median overall survival due to short follow-up. However, the median duration of response was 5 months.

This combination had a very low toxicity profile. No grade 4 to 5 toxicity was observed. Only one grade 3 non-hematological toxicity (hand-foot syndrome) was diagnosed. Toxicity profile in our study is similar to the studies mentioned above..$^{15,16}$
In conclusion, capecitabine and oral cyclophosphamide combination is a promising and well tolerated regimen in patients who previously had received taxanes and anthracyclines and in patients with cerbB2 positive tumors who received trastuzumab previously. Patients who were unresponsive to previous capecitabine or who recurred thereafter may respond to capecitabine and oral cyclophosphamide combination.

\section{REFERENCESE}

1. Bernard-Marty C, Cardoso F, Piccart MJ. Facts and controversies in systemic treatment of metastatic breast cancer. Oncologist 9: 617-623, 2004.

2. Miwa M, Ura M, Nishida M, et al. Design of a novel oral fluoropyrimidine carbamate, capecitabine, which generates 5-fluorouracil selectively in tumours by enzymes concentrated in human liver and cancer tissue. Eur J Cancer 34: 1274-1281, 1998.

3. Blum JL, Jones SE, Buzdar AU, et al. Multicenter phase II study of capecitabine in paclitaxel refractory metastatic breast cancer. J Clin Oncol 17:485,493, 1999.

4. Blum JL, Dieras V, Lo Russo PM, et al. Multicenter, phase II study of capecitabine in taxane-pretreated metastatic breast carcinoma patients. Cancer 92: 1759-1768, 2001.

5. Liu G, Franssen E, Fitch Ml et al. Patient preferences for oral versus intravenous palliative chemotherapy. J Clin Oncol 15: 110-115, 1997.

6. Wojtacki J, Wiraszka R, Rolka-Stempniewicz G, et al. Breast cancer patients' preferences for oral versus intravenous second-line anticancer therapy. Eur J Cancer 4 (Suppl 2): 159 (Abstr 381), 2006.

7. Paley M, Love N, Carlson R, et al. Preferences for oral and parenteral antitumor therapy: a survey of 260 patients with metastatic breast cancer. Proc Am Soc Clin Oncol 23 (16S): 619, 2005.

8. Fallowfield L, Atkins L, Catt S, et al. Patients' preference for administration of endocrine treatments by injection or tablets: results from a study of women with breast cancer. Ann Oncol 17: 205-210, 2006.

9. Catania C, Didier F, Leon ME, et al. Perception that oral anticancer treatments are less efficacious: development of a questionnaire to assess the possible prejudices of patients with cancer. Breast Cancer Res Treat 92: 265-272, 2005.

10. Therasse P, Arbuck SG, Eisenhauer EA, et al. New guidelines to evaluate the response to treatment in solid tumors. European Organization for Research and Treatment of Cancer, National Cancer Institute of the United States, National Cancer Institute of Canada. J Natl Cancer Inst 92: 205-216, 2000. 
11. Fumoleau P, Largiller R, Clippe C, et al. Multicentre, phase II study evaluating capecitabine monotherapy in patients with anthracycline- and taxane-pretreated meastatic breast cancer. Eur J Cancer 40: 536-542, 2004.

12. Reichardt P, von Minckwitz G, Thuss-Patience PC, et al. Multicenter phase II study of oral capecitabine (xeloda) in patients with metastatic breast cancer relapsing after treatment with a taxane-containing therapy. Ann Oncol 14: 1227-1233, 2003.

13. Wist E, Sommer H, Ostenstad B, et al. Oral capecitabine in anthracycline- and taxane-pretreated advanced/metastatic breast cancer. Acta Oncol 43: 186-189, 2004.

14. Miller KD, Chap L, Holmes F, et al. Randomized phase III trial of capecitabine compared with bevacizumab plus capecitabine in patients with previously treated metastatic breast cancer. J Clin Oncol 23: 792-799, 2005.

15. Findlay MPN, Riley GA, Ackland S, et al. Capecitabine and oral cyclophosphamide: a novel oral treatment combination for advanced cancer. Ann Oncol 13(Suppl 5): 24-25(abstract 86P), 2002

16. Ohno S, Mitsuyama S, Tamura K, Nishimura R, Tanaka M, Hamada Y, Kuroki S. Dosage of capecitabine and cyclophosphamide combination therapy in patients with metastatic breast cancer. Anticancer Res 27: 1009-1013, 2007.

\section{Correspondence}

Dr. Doğan UNCU

Gülhane Askeri Tıp Akademisi

Tıbbı Onkoloji Bilim Dalı

06018 Etlik ANKARA / TURKEY

Tel: $(+90.312) 3044174$

Faks: (+90.312) 3044150

e-mail: doganuncu@yahoo.com 